\title{
DEPENDENCE OF Cr-Cu-O CATALYSTS ACTIVITY IN THE REACTION OF ETHANOL DEHYDROGENATION ON THEIR PHASE COMPOSITION
}

\author{
S.H. Mammadova, A.A. Ahmadova \\ Azerbaijan State Oil and Industry University, \\ Azadlig 20, Baku AZ-1010, Azerbaijan \\ e-mail: salimaabbaszade@mail.ru
}

Received 15.02.2021

Accepted 24.03.2021

\begin{abstract}
The work deals with the reaction of ethanol conversion over chromium copper binary oxide catalysts. It showed that acetaldehyde is the main product of the ethanol conversion reaction. As the temperature rises, the direction of the ethanol conversion reaction shifts toward dehydration of ethanol into ethylene. Studies revealed that the atomic ratio of chromium to copper in the composition of the catalyst also has a strong effect on the activity of chromium-copper oxide catalysts. It established that samples with high chromium content in the composition of the catalyst display the greatest activity in the reaction of acetic aldehyde formation. So, on the sample $\mathrm{Cr}-\mathrm{Cu}=6-4$, the yield of acetaldehyde reaches $82.5 \%$ with a selectivity of $97.6 \%$. X-ray studies found that $\mathrm{Cr}$ - $\mathrm{Cu}$-O catalysts consist mainly of initial oxides and in some samples indicate the chemical compound. X-ray studies showed that as the copper content decreases, the degree of crystallinity increases in the studied catalytic system. Comparison of the activity of $\mathrm{Cr}-\mathrm{Cu}-\mathrm{O}$ catalysts with their crystallinity degree revealed that the rise in crystallinity degree of chromium-copper oxide catalysts leads to the increase of acetic aldehyde yield and its selectivity in the ethanol conversion reaction.
\end{abstract}

Keywords: ethanol dehydrogenation, binary catalysts, crystallinity.

DOI: $10.32737 / 2221-8688-2021-1-25-31$

\section{Introduction}

As is known, renewable bioethanol is one of the promising raw materials for the production of various chemical compounds [1$3]$. The conversion reaction of ethanol makes it possible to obtain chemicals like acetaldehyde, acetic acid, diethyl ester, etc. For the reactions of ethanol conversion, various catalytic systems are used on the basis of oxides of chrome, zinc, copper, etc. [4, 5]. Previously we showed that at high speed the ethanol is converted into acetone, acetic acid on various binary chromium-copper containing catalysts $[6,7]$. It is known that the phase composition of the catalyst and its structural properties, can have a strong effect on its activity $[8,9]$. One of the structural properties of the catalyst is its crystallinity which depends both on basic compounds used for its preparation and on conditions under which it is prepared. For this reason, the present work deals with the study of the dependence of chromiumcopper oxide catalysts activity in the dehydrogenation reaction of ethanol on their crystallization rate.

\section{Experimental part}

Binary chromium copper oxide catalysts of various compositions were prepared by means of co-precipitation from aqueous solutions of chromium and copper nitrate. The resulting mixture was successively evaporated and dried at $100-120^{\circ} \mathrm{C}$, decomposed until nitrogen oxides were completely isolated at $250^{\circ} \mathrm{C}$, and then calcined at $600^{\circ} \mathrm{C}$ within 10 hours. Thus, 9 catalysts with an atomic ratio of elements from $\mathrm{Cr}: \mathrm{Cu}=1: 9$ to $\mathrm{Cr}: \mathrm{Cu}=9: 1$ were 
synthesized and the activity of the synthesized catalysts in the reaction of ethanol conversion and butene- 1 isomerization explored in a flow unit with a tubular reactor in the temperature range $100-500^{\circ} \mathrm{C}$. Also, $5 \mathrm{ml}$ of the given catalyst with a grain size of $1.0-2.0 \mathrm{~mm}$ was loaded into the reactor, and its activity in the ethanol conversion reaction was studied.
Ethanol conversion was carried out in a stream of nitrogen. Ethanol and its conversion products were determined by chromatography method. $\mathrm{X}$-ray studies of binary chrome-copper oxide catalysts were carried out on a Bruker automatic D2 Phaser powder diffractometer $(\mathrm{CuK} \alpha$ radiation, Ni filter, $3 \leq 2 \theta \geq 80^{\circ}$ ).

\section{Results and discussion}

Studies found that the main product of ethanol over chrome-copper oxide catalysts conversion was acetic aldehyde. Ethylene, acetone, ethyl acetate, carbon dioxide, and carbon dioxide and other decomposition products were also formed as a by-product. Fig. 1 shows the effect of the reaction temperature on the yields of ethanol conversion products on a $\mathrm{Cr}: \mathrm{Cu}=6: 4$ catalyst. As can be seen from Fig. 1 , acetic aldehyde is formed in the greatest amount on the $\mathrm{Cr}: \mathrm{Cu}=6: 4$ catalyst. Fig. 1 reveals that the reaction of ethanol conversion on the explored catalyst starts at a temperature of $150^{\circ} \mathrm{C}$ and at this temperature only acetic aldehyde is formed in an amount of $9.9 \%$. Increase in the reaction temperature leads to the formation of other reaction products. Maximum yield of acetic aldehyde reaches $82.5 \%$ at $300^{\circ} \mathrm{C}$.

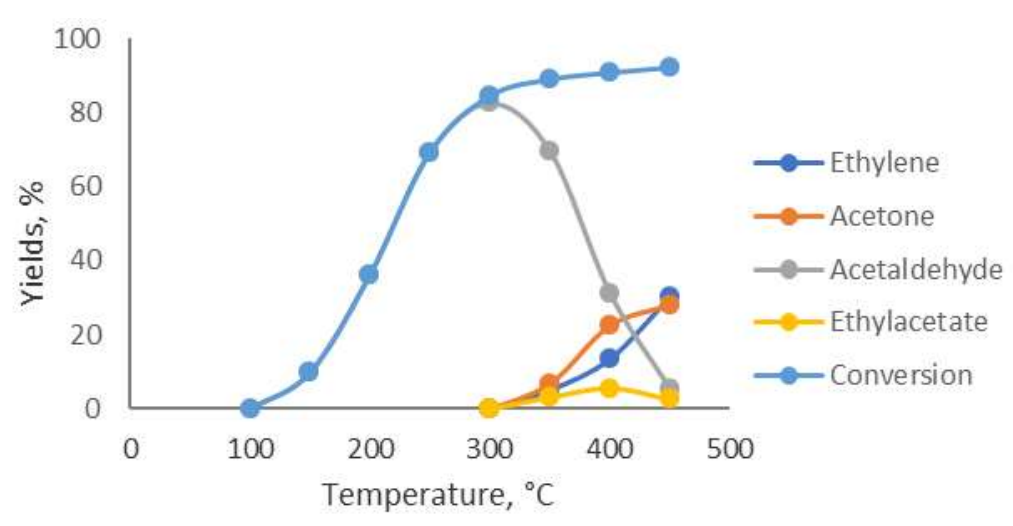

Fig. 1. Effect of temperature on the yields of ethanol conversion products on $\mathrm{Cr}: \mathrm{Cu}=6: 4$ catalyst.

The formation of ethylene, acetone and carbon dioxide begins at a temperature of $350^{\circ} \mathrm{C}$. Fig. 1 shows that the yields of ethylene and acetone increase as the reaction temperature rises. The highest yields of ethylene and acetone are observed at a temperature of $450^{\circ} \mathrm{C}$ to make up 30.2 and $28 \%$ respectively. As for the formation of ethyl acetate, it is observed in the temperature range 350 and $450^{\circ} \mathrm{C}$ and does not exceed $5.6 \%$. The maximum ethanol conversion on the $\mathrm{Cr}: \mathrm{Cu}=1: 9$ catalyst reaches $92.1 \%$ at $450^{\circ} \mathrm{C}$.
Our preliminary studies revealed that the atomic ratio of cerium to copper strongly affects the activity of chromium-copper oxide catalysts in the reaction of ethanol conversion. In this regard, we studied the effect of the composition of chromium copper catalyst on its activity. Table 1 shows the ethanol conversion, yields and selectivity of acetic aldehyde on chromium copper oxide catalysts of various compositions at a temperature of $300^{\circ} \mathrm{C}$.

As can be seen from Table 1, the yield of acetic aldehyde with an increase in the chromium content in the catalyst composition first 
decreases from $46.2 \%$ on the catalyst $\mathrm{Cr}: \mathrm{Cu}=$ $1: 9$ to $32.3 \%$ on the catalyst $\mathrm{Cr}: \mathrm{Cu}=3: 7$ and then increases to pass through a maximum of $82.5 \%$ on the catalyst $\mathrm{Cr}: \mathrm{Cu}=6: 4$. The table also shows that the selectivity of the reaction for acetic aldehyde with an increase in the chromium content in the catalyst increases to almost $98 \%$ and then remains unchanged. The maximum ethanol conversion in the studied samples reaches $84.5 \%$.

Table 1. Dependence of the yield and selectivity of acetic aldehyde on the atomic ratio of chromium to copper. $\mathrm{T}=300^{\circ} \mathrm{C}$.

\begin{tabular}{|l|l|l|l|l|l|l|l|l|l|}
\hline $\mathrm{Cr} / \mathrm{Cu}$ atom ratio & $1: 9$ & $2: 8$ & $3: 7$ & $4: 6$ & $5: 5$ & $6: 4$ & $7: 3$ & $8: 2$ & $9: 1$ \\
\hline Reaction products & \multicolumn{8}{|c|}{ Yields, \% } \\
\hline $\mathrm{CH}_{3} \mathrm{CHO}$ & 46.2 & 42.3 & 32.3 & 53.9 & 70.9 & 82.5 & 75.9 & 61.1 & 57 \\
\hline Conversion & 73.8 & 63.3 & 58.6 & 67.9 & 72.6 & 84.5 & 75.9 & 62.5 & 57.8 \\
\hline Selectivity & 62.6 & 66.8 & 55.1 & 79.4 & 97.6 & 97.6 & 100 & 97.8 & 98.6 \\
\hline
\end{tabular}

Thus, based on the conducted studies, it can be said that acetic aldehyde is the main reaction product on chromium-copper catalysts and its yield reaches $82.5 \%$ with a selectivity of $97.6 \%$. The yield and distribution of reaction products on chromium copper catalysts depends both on the reaction temperature and the atomic ratio of chromium to copper.

As is known, the phase composition of the catalyst, i.e., its structural properties, can have a profound effect on its activity. One of the structural properties of the catalyst is its crystallinity which depends both on basic compounds used for its preparation and conditions under which it is prepared. For this reason, we have studied the dependence of the activity of ethanol dehydrogenation reaction of catalysts synthesized by us on their crystallization rate.

$\mathrm{X}$-ray studies of $\mathrm{Cr}-\mathrm{Cu}-\mathrm{O}$ catalytic system shows that in addition to phases of the two primary oxides the chemical compound phase $\mathrm{CuCr}_{2} \mathrm{O}_{4}$ is formed. The crystallographic characteristics of the identified phases are given in Table 2.

Table 2. Crystallographic properties of phases formed in the $\mathrm{Cr}-\mathrm{Cu}-\mathrm{O}$ catalytic system

\begin{tabular}{|c|c|c|c|c|c|c|c|}
\hline \multirow{2}{*}{$\begin{array}{l}\text { Chemical } \\
\text { compound }\end{array}$} & \multirow[t]{2}{*}{ Syngonia } & \multirow{2}{*}{$\begin{array}{l}\text { Volume } \\
\text { group }\end{array}$} & \multicolumn{4}{|c|}{ Lattice parameters } & \multirow{2}{*}{$\begin{array}{c}\mathrm{Z}, \text { number of } \\
\text { molecules }\end{array}$} \\
\hline & & & $\mathrm{a}, \AA$ & $\mathrm{B}, \AA$ & $\mathrm{c}, \AA$ & angle, & \\
\hline $\mathrm{CuO}$ & Monoclinic & $\mathrm{Cc}$ & 4.692 & 3.428 & 5.137 & 99.54 & 4 \\
\hline $\mathrm{Cr}_{2} \mathrm{O}_{3}$ & Rhombohedral & $\mathrm{R} \overline{3} \mathrm{c}$ & 4.960 & - & 13.59 & - & 6 \\
\hline $\mathrm{CuCr}_{2} \mathrm{O}_{4}$ & Tetragonal & $\mathrm{I} \overline{4} 2 \mathrm{~d}$ & 6.04 & - & 7.78 & - & 4 \\
\hline
\end{tabular}

Analysis of diffraction curves in the $\mathrm{Cr}$ $\mathrm{Cu}-\mathrm{O}$ system shows the formation of 3 phases $\mathrm{Cr}_{2} \mathrm{O}_{3}, \mathrm{CuO}$ and $\mathrm{CuCr}_{2} \mathrm{O}_{4}$ in all samples. Fig. 2 shows combined diffraction curves of all nine ratios $(\mathrm{m} \mathrm{Cr} / \mathrm{nCu})$. For comparative analysis, diffraction curves of $\mathrm{Cr}_{2} \mathrm{O}_{3}$ and $\mathrm{CuO}$ oxides are shown at the beginning and end of diffraction curves. X-ray analysis reveals that all samples contain mainly 2 phases, $\mathrm{Cr}_{2} \mathrm{O}_{3}$ and $\mathrm{CuO}$. A regular change in the intensity of diffraction reflexes indicates the maintenance of the phase ratio of all components. 


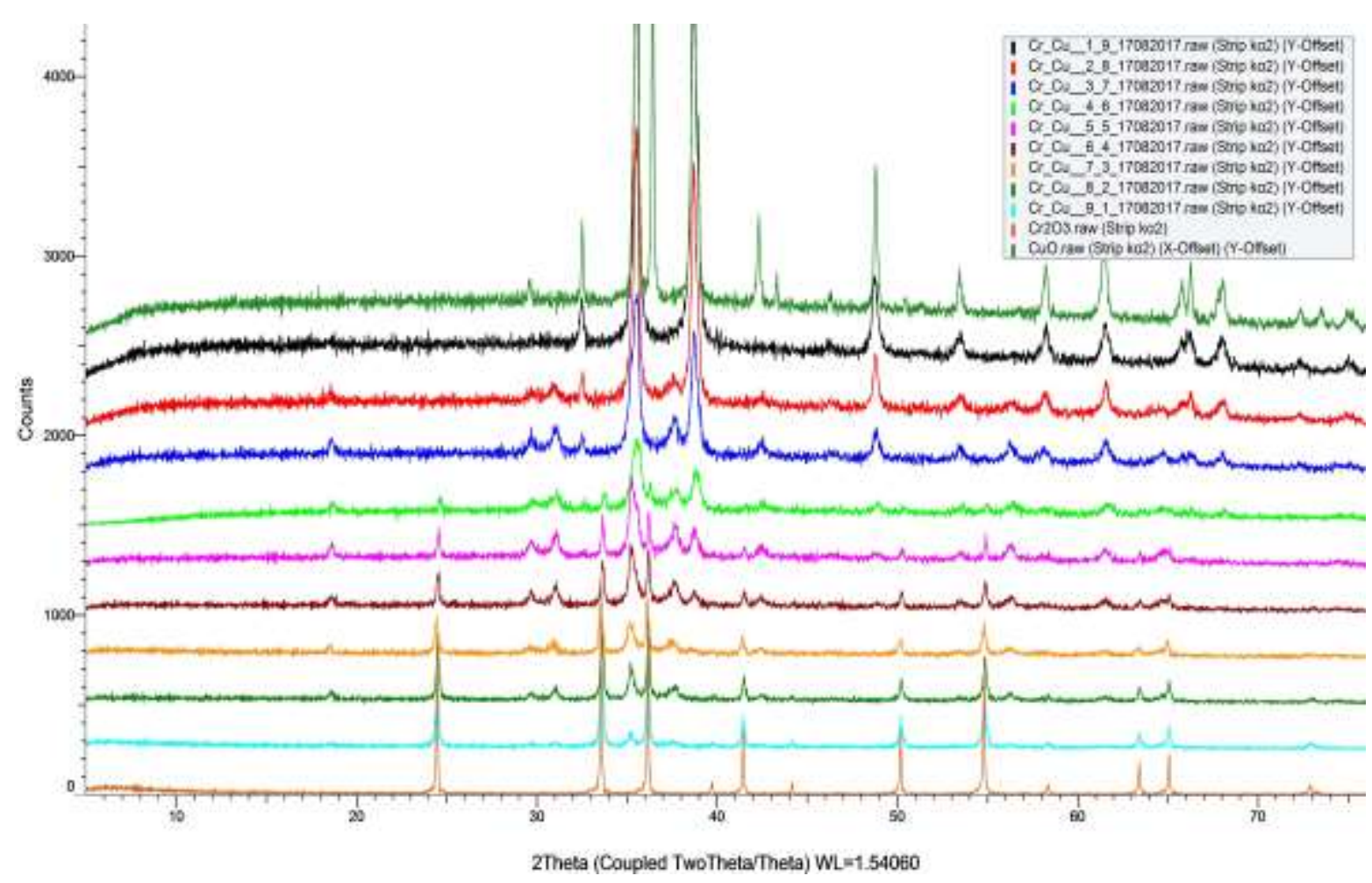

Fig. 2. Diffractograms of chromium and copper oxide, as well as $\mathrm{Cr}-\mathrm{Cu}-\mathrm{O}$ catalysts for all nine ratios.

Also, we calculated crystallization rates of all phases in the D2 Phaser using the DIFFRAC.EVA program. The results obtained are shown in Table 3. As can be seen from Table 3 , the degree of crystallinity increases in the studied catalytic system as the copper content decreases. Thus, as the chrome content in the $\mathrm{Cr}-\mathrm{Cu}-\mathrm{O}$ catalytic system increases, the crystallization rate rises from $41.6 \%$ to $73.3 \%$.

Table 3. Crystallinity degree of samples of $\mathrm{Cr}-\mathrm{Cu}-\mathrm{O}$ catalytic system.

\begin{tabular}{|l|c|c|c|c|c|c|c|c|c|}
\hline $\mathrm{Cr}: \mathrm{Cu}$ ratio & $1: 9$ & $2: 8$ & $3: 7$ & $4: 6$ & $5: 5$ & $6: 4$ & $7: 3$ & $8: 2$ & $9: 1$ \\
\hline Degree of crystallinity, \% & 41.6 & 41.9 & 50.2 & 57.3 & 64.4 & 67.1 & 69.7 & 73.3 & 71.2 \\
\hline
\end{tabular}

Fig. 3 shows the dependence of the yield of acetaldehyde, the selectivity of the process on acetaldehyde and the conversion of ethanol on the degree of crystallinity of binary chromiumcopper oxide catalysts. Fig. 3 indicates that as the crystallinity of chromium-copper oxide catalysts increases, the yield of acetaldehyde, the selectivity of the acetaldehyde process, and the conversion of ethanol change symmetrically. Also, it has to be kept in mind that when the catalyst has a high crystallinity, the ethanol is converted to acetaldehyde at $100 \%$. This indicates that the rise in the crystallinity of chromium-copper oxide catalysts increases the selectivity of acetaldehyde process. On that basis, in order to increase the selectivity of ethanol conversion into acetaldehyde, it is necessary to synthesize the catalyst with a high degree of crystallinity. 


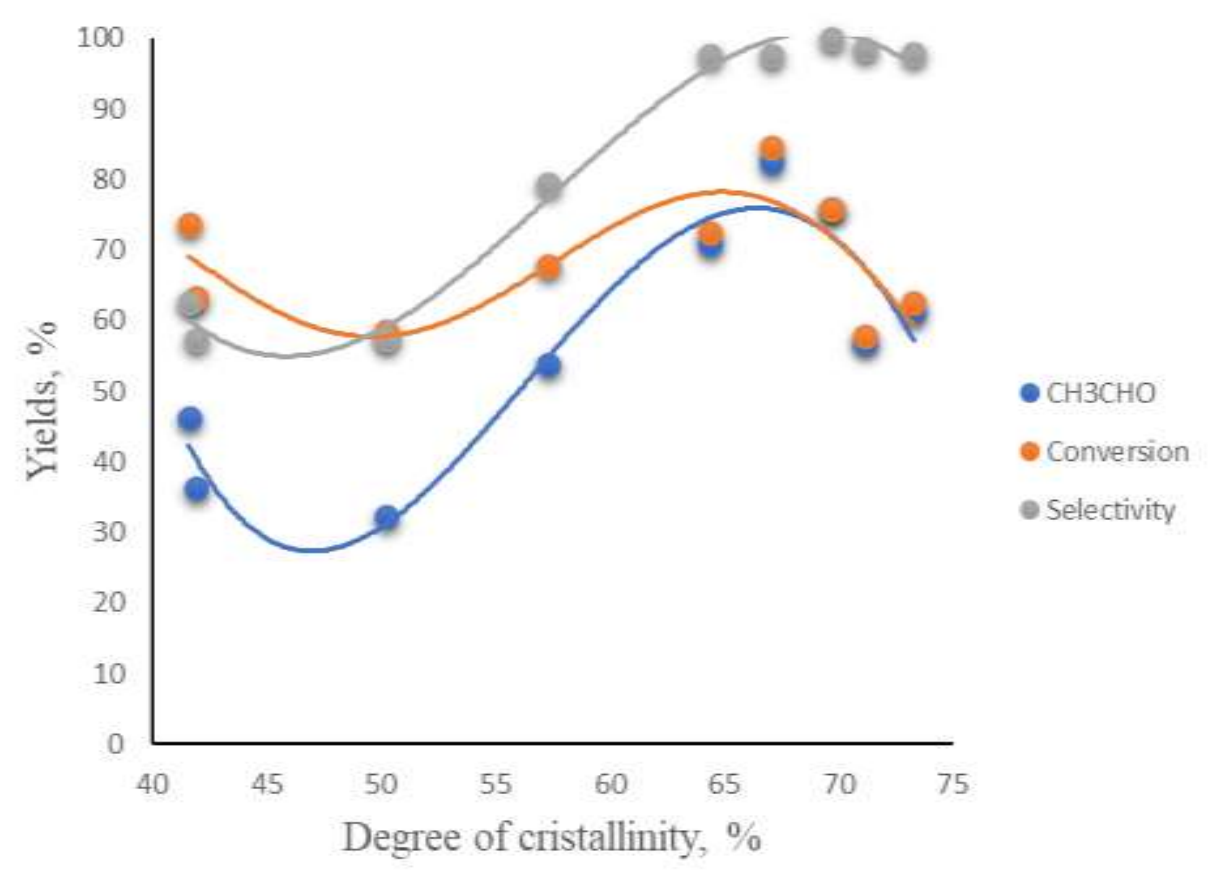

Fig. 3. Dependence of the activity of chromium-copper oxide catalyst in the ethanol dehydrogenation reaction on the degree of crystallinity. $\mathrm{T}=300{ }^{\circ} \mathrm{C}$.

\section{Conclusions}

- Main product of the ethanol conversion reaction over chromium-copper oxide catalysts is acetic aldehyde, and its yield reaches up to $82.5 \%$ with selectivity $97.6 \%$.
- Increase in crystallinity degree of chromium-copper oxide catalysts leads to rise in the yield of acetic aldehyde and its selectivity in the ethanol conversion reaction.

\section{References}

1. Megumu Inaba, Kazuhisa Murata, Masahiro Saito \& Isao Takahara. Ethanol conversion to aromatic hydrocarbons over several zeolite catalysts. Reaction Kinetics and Catalysis Letters. 2006, vol. 88, pp. 135-141.

2. Weiping Wang, Zhifei Wang, Yan Ding, Jinyu Xi \& Gongxuan Lu. Partial Oxidation of Ethanol to Hydrogen over $\mathrm{Ni}-\mathrm{Fe}$ Catalysts. Catalysis Letters. 2002, vol. 81, pp. 63-68.

3. Dapeng Liu, Yan Liu, Eileen Yi Ling Goh, Christina Jia Ying Chu, Chuandayani Gunawan Gwie, Jie Chang, Armando Borgna. Catalytic conversion of ethanol over ZSM-11 based catalysts. Applied Catalysis A: General, 2016, vol. 523, pp. 118-129.

4. Hala R. Mahmoud. Highly dispersed $\mathrm{Cr}_{2} \mathrm{O}_{3}$ $\mathrm{ZrO}_{2}$ binary oxide nanomaterials as novel catalysts for ethanol conversion. Journal of Molecular Catalysis A. Chemical. 2014, vol. 392, pp. 216-222.

5. Isabel C. Freitas, Jean Marcel R. Gallo, José Maria C. Bueno \& Clélia M. P. Marques. The Effect of $\mathrm{Ag}$ in the $\mathrm{Cu} / \mathrm{ZrO}_{2}$ Performance for the Ethanol Conversion. Topics in Catalysis. 2016, vol. 59, pp 357365.

6. Mammadova S.H., Aghayeva K.Kh. Conversion of ethanol over binary copper containing catalysts. Chemical Problems. 2020, vol.18, no 2, pp. 199-205.

7. Mammadova S.H., Garaybayli S.A., Baghiyev V.L. A study of the phase composition of copper-cerium oxide system. In: 5th International School-Conference on Catalysis for Young Scientists, Catalyst 
Design: From Molecular to Industrial Level, May 20-23, 2018, Moscow, Russia, ABSTRACTS, Novosibirsk, PP-V-12, p.188.

8. Kushal Singh, Kundan Kumar, Saurabh Srivastava, Anirban Chowdhury. Effect of rare-earth doping in $\mathrm{CeO}_{2}$ matrix: Correlations with structure, catalytic and visible light photocatalytic properties. Ceramics International, 2017, vol. 43, issue
18, pp. 17041-17047.

9. Elena A.Baranova E.A, Monica A.Padilla, Barr Halevi, Tariq Amir, Kateryna Artyushkova, Plamen Atanassov. Electrooxidation of ethanol on PtSn nanoparticles in alkaline solution: Correlation between structure and catalytic properties. Electrochimica Acta, 2012, vol. 80 , pp. $377-382$.

\title{
ETANOLUN DEHIDROGENLOSMOSI REAKSIYYSINDA Cr-CU-O KATALUZATORLARININ AKTIVLIYININ ONLARIN FAZA TORKIBIINDON ASILILIĞI
}

\author{
S.H. Mammadova, A.A. Ohmodova \\ Azarbaycan Dövlat Neft va Sanaye Universiteti, \\ Azadlıq 20, Bakı AZ-1010, Azorbaycan \\ e-mail: salimaabbaszade@mail.ru
}

İşdə xrom vo mis torkibli binar oksid katalizatorları üzorindo etanolun çevrilmosi reaksiyası öyranilmişdir. Göstarilmişdir ki, etanolun çevrilməsi reaksiyasının asas məhsulu sirka aldehididir. Reaksiya temperaturunun məhsulların çıxımına təsiri öyronilmişdir. Müəyyən edilmişdir ki, temperatur artdıqca etanolun çevrilmə reaksiyasının istiqaməti etanolun etilenə dehidratlaşması istiqamətina doğru dəyişir. Tədqiqatlar göstərmişdir ki, xromun misa atom nisbəti katalizatorların aktivliyina güclü təsir göstərir. Müəyyən edilmişdir ki, sirka aldehidinin amala galməsi reaksiyasında katalizatorun tərkibində xromun miqdarl yüksək olan nümunələri daha çox aktivlik göstarir. Bela ki Cr-Cu=6-4 tarkibli nümunada asetaldehidin çıxımı 82.5\%, selektivlik isa 97.6\% -a çatır. Rentgenqrafik tədqiqatlar $\mathrm{Cr}$-Cu-O katalizatorlarının əsasən oksidlərdən ibarət olduğunu göstarir, bazi nümunวlardə elacə də $\mathrm{CuCr}_{2} \mathrm{O}_{4}$ müşahida olunur. $\mathrm{Cr}-\mathrm{Cu}$-O katalitik sistemdə misin miqdarı azaldıqca kristallik daracəsi artır. Kristalliklik daracəsi artıqca sirka aldehidinin çıxımı, selektivliyi va etanolun konvensiyasi artır.

Açar sözlor: etanolun dehidrogenloşməsi, binar katalizatorlar, kristalliklik.

\section{ЗАВИСИМОСТЬ АКТИВНОСТИ СТ-СИ-О КАТАЛИЗАТОРОВ В РЕАКЦИИ ДЕГИДРИРОВАНИЯ ЭТАНОЛА ОТ ИХ ФАЗОВОГО СОСТАВА}

\section{С.Г. Мамедова, А.А. Ахмедова}

Азербайджанский Государственный Университет Нефти и Промышленности, Азадльг 20, Баку AZ-1010, Азербайджан e-mail: salimaabbaszade@mail.ru

В данной работе реакиия превращения этанола изучена на бинарных катализаторах, состоящих из оксида хрома и меди. Показано, что ацетальдегид является основным продуктом реакции превращения этанола. Установлено, что с повышением температуры направление реакиии превращения этанола смещается в сторону дегидратации этанола до этилена. Исследования показали, что атомное отношение хрома $\kappa$ меди в составе катализатора также оказывает сильное влияние на активность катализаторов. 
Установлено, что наибольшей активностью в реакции образования уксусного альдегида обладают образиы с высоким содержанием хрома в составе катализатора. Так, на образие $\mathrm{Cr}-\mathrm{Cu}=6-4$ выход ацетальдегида достигает 82.5\% при селективности 97.6\%. Рентгеновские исследования показали, что катализаторы $\mathrm{Cr}$-Cu-O состоят в основном из оксидов, а в некоторых образиах присутствует $\mathrm{CuCr}_{2} \mathrm{O}_{4}$. Рентгенографические исследования также показали, что с уменьшением содержания меди степень кристалличности исследуемой каталитической системы увеличивается. Сравнение активности $\mathrm{Cr}$-Си-О-катализаторов со степенью их кристалличности показало, что увеличение степени кристалличности хром-медно-оксидных катализаторов приводит $\kappa$ увеличению выхода уксусного альдегида и его селективности в реакции конверсии этанола.

Ключевые слова: дегидрирование этанола, бинарные катализаторы, кристалличность. 